\title{
MANAGING DUNE LANDSCAPE CHANGES AT JOCKEY'S RIDGE STATE PARK, NORTH CAROLINA
}

\author{
ONDREJ MITAS, ${ }^{*}$ HELENA MITASOVA, $†$ GENE BROTHERS, $\ddagger$ AND KATHERINE WEAVER§ \\ *Academy for Tourism, NHTV Breda University of Applied Sciences, \\ Breda, North Brabant, The Netherlands \\ †Department of Marine, Earth and Atmospheric Sciences, \\ North Carolina State University, Raleigh, NC, USA \\ $\ddagger$ Department of Parks, Recreation, and Tourism Management, \\ North Carolina State University in Raleigh, NC, USA \\ $\S$ Division Conservation Science Office, The Nature Conservancy, Boston, MA, USA
}

\begin{abstract}
Coastal dunes are challenging to manage due to their dynamic nature, vulnerable ecosystems, and recreational demand. A limited management approach was studied at Jockey's Ridge, the largest active dune on the US Atlantic coast. Visitor experience data, digital elevation models, and informal stories and photos were integrated in a case study approach. Data revealed the value of an integrated management approach that preserved the dune as a unique "living" geomorphological feature with interventions limited to the park borders. The accessibility of the dune to visitors facilitated intense, enjoyable interactions with nature. Elevation data show that the management approach has maintained the dune's unique naturally dynamic character, revealing the benefits of preserving processes rather than features.
\end{abstract}

Key words: Coastal dunes; Dynamic landscape; Visitor management; Visitor impacts; Conservation

\section{Introduction}

Sand dunes are a defining feature of coastal landscapes. In many regions they are protected as natural parks due to their unique landforms and fragile ecosystems (Yang, Madden, Kim, \& Jordan, 2012). At the same time they are popular tourist locations that offer hiking, ocean views, and a chance to learn about ecosystems. As tourist attractions in coastal regions, they are often secondary to the beach and commercial attractions. Nevertheless, millions of visitors flock to coastal dunes such as those in the eastern US, Japan, and France every year.

The management of coastal dunes is challenging due to their dynamic nature. Sand transport can interfere with buildings and infrastructure. Concerns arise when dunes are opened to recreational activities, which may impact fragile ecosystems. The limited 
literature on recreational areas with dunes focuses on two main themes: managing natural processes, and managing the experiences and impacts of visitors. Some scholars (e.g., Meulen \& Salman, 1996) advocate for integration of these perspectives, but even then the distinction between human activities and natural processes remains stark. The literature gives ample guidance on managing natural processes, but recommendations for managing human activities, especially recreation, are untested.

\section{The Natural Element: Dunes as Dynamic Landforms}

Dune fields can be found on sandy coasts all over the world. Coastal dunes are formed by wind transport and can reach 50-100 $\mathrm{m}$ in height and extend over $1 \mathrm{~km}^{2}$ (e.g., The Great Dune of Pyla; Froidefond \& Legigan, 1985). Depending on local conditions, such as sand availability, vegetation, and wind intensity and direction, several types of dunes can form on barrier islands (Pelletier, Mitasova, Harmon, \& Overton, 2009). Common are linear dunes parallel to the shoreline, and back island dunes, which may have crescentic or parabolic shapes. Exposed to steady coastal winds, these dunes often migrate and evolve, creating a highly dynamic landscape. Geological studies performed at some of these dunes show buried organic matter and soil layers (Berger, Murray, \& Havholm, 2003; Havholm et al., 2004; Tastet \& Pontee, 1998), indicating periodic transformations of forested landscapes into active dunes over several centuries.

Under certain conditions, unvegetated dunes grow and migrate, interfering with surrounding built environments such as roads and houses. On the other hand, dunes with limited sand supply and expanding vegetation degrade and eventually transform into stable landscapes (Pelletier et al., 2009). Approaches to management of active dunes range from complete stabilization to limited intervention combined with occasional cleaning of roads from excess sand. Similarly, approaches to managing the vegetation, and thus dune stability, range from (a) removal with the goal of increasing sand transport and preventing dune transformation into a forested landscape, to (b) planting vegetation in carefully selected patterns to limit sand transport and stabilize the dunes, and (c) no interference with vegetation at all (Martinez \&
Psuty, 2004). Scientific studies that combine climatology, geology, and biology can improve the understanding of dune evolution at a particular location and provide fundamental information for its management. However, this information must be considered in the context of a natural resource site with human activity, not as a pristine, isolated feature.

\section{The Human Element: Managing Dunes for Recreation}

The natural processes of coastal dunes often interact with human activities such as recreation. Approaches to managing these interactions vary. Some dunes are completely closed to human visitors. Many, on the other hand, are open, allowing free movement on foot over the entire dune surface. Furthermore, some are also open to bicycles and motor vehicles. Some dunes even have fixed structures to facilitate recreation such as sandboarding (descending a dune slope on a snowboard) and hang gliding.

Academic research exploring management practices at dunes is sparse but unequivocal. Over the past two decades, numerous scholars have found that dunes are under threat from human activity and should be protected to save natural flora, fauna, and landforms. There are often major concerns that opening dunes to recreational activities will damage their fragile ecosystems and interfere with natural processes. Yet the desire of individuals to engage in recreational activities such as hiking, hang gliding, and sandboarding is well known. The standpoint of research in Israel (Kuitel, 2001), western Europe (Davies, Williams \& Curr, 1995), Egypt (Batanouny, 1999), and the US (Yang et al., 2012) is that human activities are not a part of nature and thus not part of the inherent value of the landscape. Natural flora, fauna, sand, and dune erosion and accretion processes, on the other hand, are presented as inherently valuable and worth protecting. Human activities discussed as urgent threats in the literature are urbanization and large-scale tourism development. Less clear from this research is if any recreational use should be allowed, and, if so, how it should be managed.

Some studies (e.g., Batanouny, 1999) do not make a distinction between urbanization and recreational use, grouping together all human activity as undesirable regardless of impact. Others do make this distinction (e.g., Meulen \& Salman, 1996) but give only 
anecdotal suggestions about managing recreation. In other words, scholars have freely given their opinions of how dunes "should" be opened or closed to recreationists, but little evidence exists of how recreation management policies are implemented, and how well they work. Meulen and Salman (1996) advocate a management approach that integrates the various perspectives discussed-geophysical and biotic processes, large-scale development, tourism, and recreational use. They only state how this approach should work, not how it does work. The study presented here focuses on documenting these outcomes.

The literature review demonstrates that dunes present an interesting variety of management challenges. Research on dune management generally separates natural processes from human ones, prioritizing the natural processes in management decisions. It is not clear from this research how human interests such as recreation at dune landscapes should be managed. Thus, the present study explores the integrated management approach used at Jockey's Ridge State Park located on the sandy barrier islands of the US Atlantic coast.

\section{Methods}

\section{Study Design}

The literature review shows a gap in understanding how human interests, especially recreation, should be managed at dune sites. Gaining such understanding requires a focus on depth and integration rather than breadth and generalization. Therefore, a case study design was selected. Specifically, multiple interactions between human activities and natural processes were examined at a site where these interactions were especially complex and challenging. This site includes the tallest active sand dune on the US Atlantic coast, Jockey’s Ridge.

\section{Study Site}

Typification. Jockey's Ridge is protected as a State Park of North Carolina, located in the southeastern US between the tourist communities of Nags Head and Kitty Hawk on the Outer Banks (Fig. 1). The Outer Banks are narrow barrier islands located off the east coast of the US mainland. The landscape of the Outer Banks is, not surprisingly, sandy and dynamic. Nevertheless, the idyllic atmosphere, wide beaches, and rich 19th century history of the islands make them tremendously attractive to tourists. Thus, despite technical challenges, large portions of the Outer Banks have been built over with vacation homes and cottages, and a highway connecting the islands. There are no high-rise hotels and very few buildings higher than three stories, but the density of small accommodations is high. Furthermore, there are many commercial buildings along the highway.

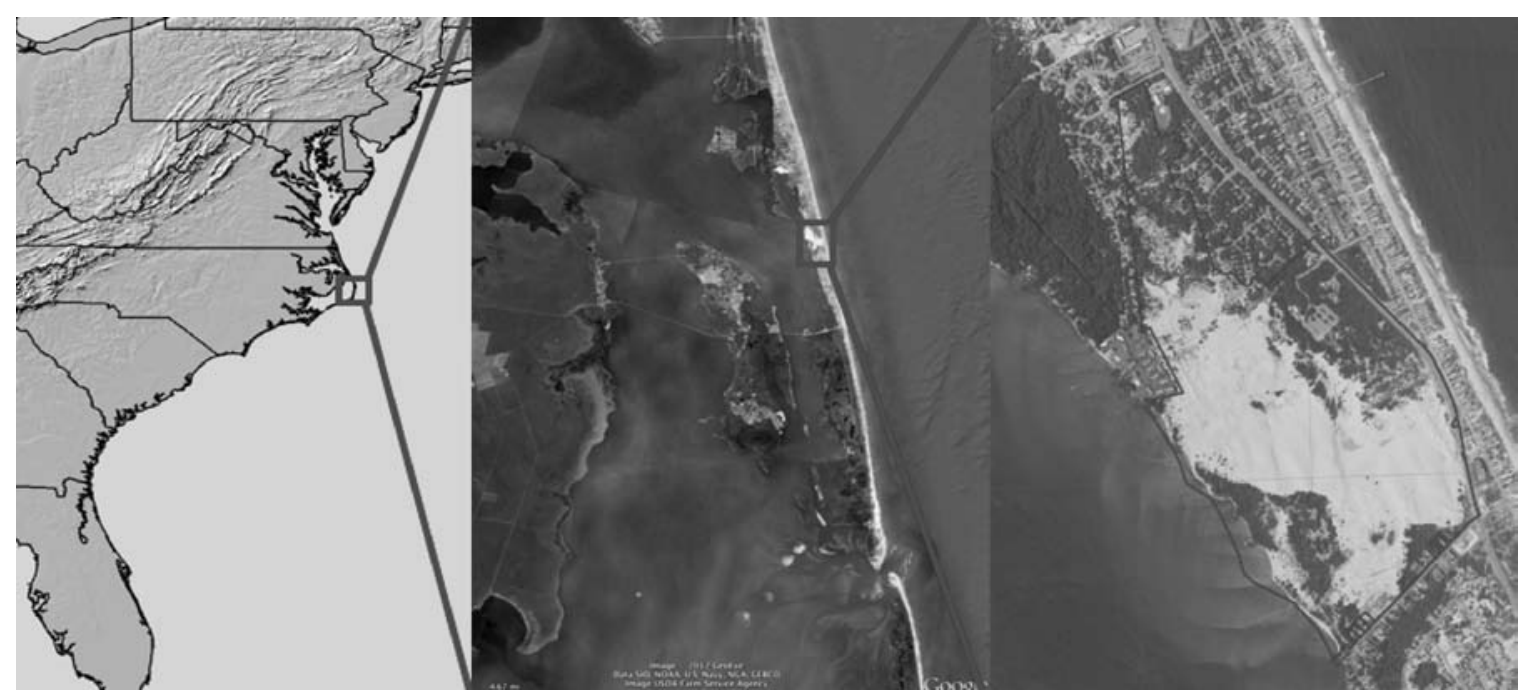

Figure 1. Location and digital elevation model of Jockey’s Ridge State Park on the Outer Banks, barrier islands on the coast of North Carolina, USA. 
Among this development rises a large and prominent sand dune, bordered on the south by a small residential road and homes, on the east by a highway and Atlantic Ocean, on the west by Roanoke Sound, and on the north by a small protected forest and residential area. The current dune field is composed of coalescent crescentic and parabolic dunes with five parallel ridges (Weaver, 2011) (Fig. 1).

The status of the site as a North Carolina State Park affords several facilities. From the highway there is a small road leading into the park. At the base of the dune field, this road opens into a parking lot. Adjoining the parking lot are two one-story buildings, which include a visitor center with a small museum, restrooms, and park management offices. The other building is leased by a concessionaire that offers hang gliding lessons on the dune. From these buildings, a 100-m boardwalk leads to a viewing platform that gives visitors their first direct experience with the dunes. From the viewing platform, a stairway leads down to the sand where many visitors begin a climb to the top of the dune. Nature trails with information about the fauna and flora are established around the dune. A second parking lot on the western side of the park attracts visitors who are interested in access to Roanoke Sound rather than climbing the dune.

At present, Jockey's Ridge is one of the most visited state parks in North Carolina, with over 1 million visitors in 2011. A majority of visitors attend in family groups and stay for 1-3 hours (Mitas, 2006). The most popular activities at Jockey's Ridge are walking and climbing on the dunes, enjoying the views and taking photos, and observing wildlife. The latter activity is facilitated by park staff, who offer several hands-on wildlife programs, such as bird watching, during the high season. A minority of visitors also fly kites, sandboard, or hang glide from the dunes (Fig. 2).

History. Historical and geological data indicate that the landscape in this area has alternated between active dunes and stable forest at varying time intervals of 100-400 years (Havholm et al., 2004). Around 1838, when the first hotel was built in the area (Kingsley \& Bachman, 2009), the partially forested ridge began to turn into an active dune. The increasing movement of the sand caused problems for the hotel. By 1850 the hotel guest rooms were equipped with shovels for sand removal and eventually the hotel was lost to the dune. By 1900 the nearby village of Nags Head was a small, but well-established vacation destination with dozens of cottages. There was no large-scale development until the 1960s, however.

In the early 1970s the site of Jockey's Ridge was earmarked for development of additional vacation cottages. In a famous incident, in 1973, local resident and frequent visitor Carolista Baum stood in front of a bulldozer that was preparing land for construction on the Jockey's Ridge site and thus singlehandedly prevented development at the site. A variety of energetic community-based efforts to raise money and public support led the State of North Carolina to purchase the land containing Jockey's Ridge with the aim of creating a State Park in 1975.

The dune has turned out to be more dynamic than anticipated when the park was established. Its southerly migration has led to the covering of a minigolf course, caused numerous problems on neighboring roads, and threatened several homes. By the mid-1990s two major management issues emerged: (a) sand leaving the park along its southern and eastern boundary and (b) significant loss of dune elevation. This decline has reduced the appeal of Jockey's Ridge to some recreational users, especially hang gliders. The main dune, which was once too high for beginner gliders, is now used for training. Dune stabilization using fences and even pumping sand to the top of the main dune were proposed as possible solutions. Eventually, the State of North Carolina turned to scientists for help to quantify the changes, investigate the processes driving the changes, and propose solutions. The research results were summarized in several articles (Havholm et al., 2004; Judge, Courtney, \& Overton, 2000; Runyan \& Dolan, 2001). The researchers recommended transporting the sand from the southern park boundaries to the north, with the hope that the relocated sand will be eventually blown by wind onto the dunes and help sustain their elevation. When destruction of a home seemed imminent in 2003, a large sand relocation was implemented (Fig. 3). The southernmost dune in the park was removed and trucked to the north end of the park. While that sand appears to remain in the north, the highest ridges of the dune field have stabilized at a height of 21-22 m (Weaver, 2011). 

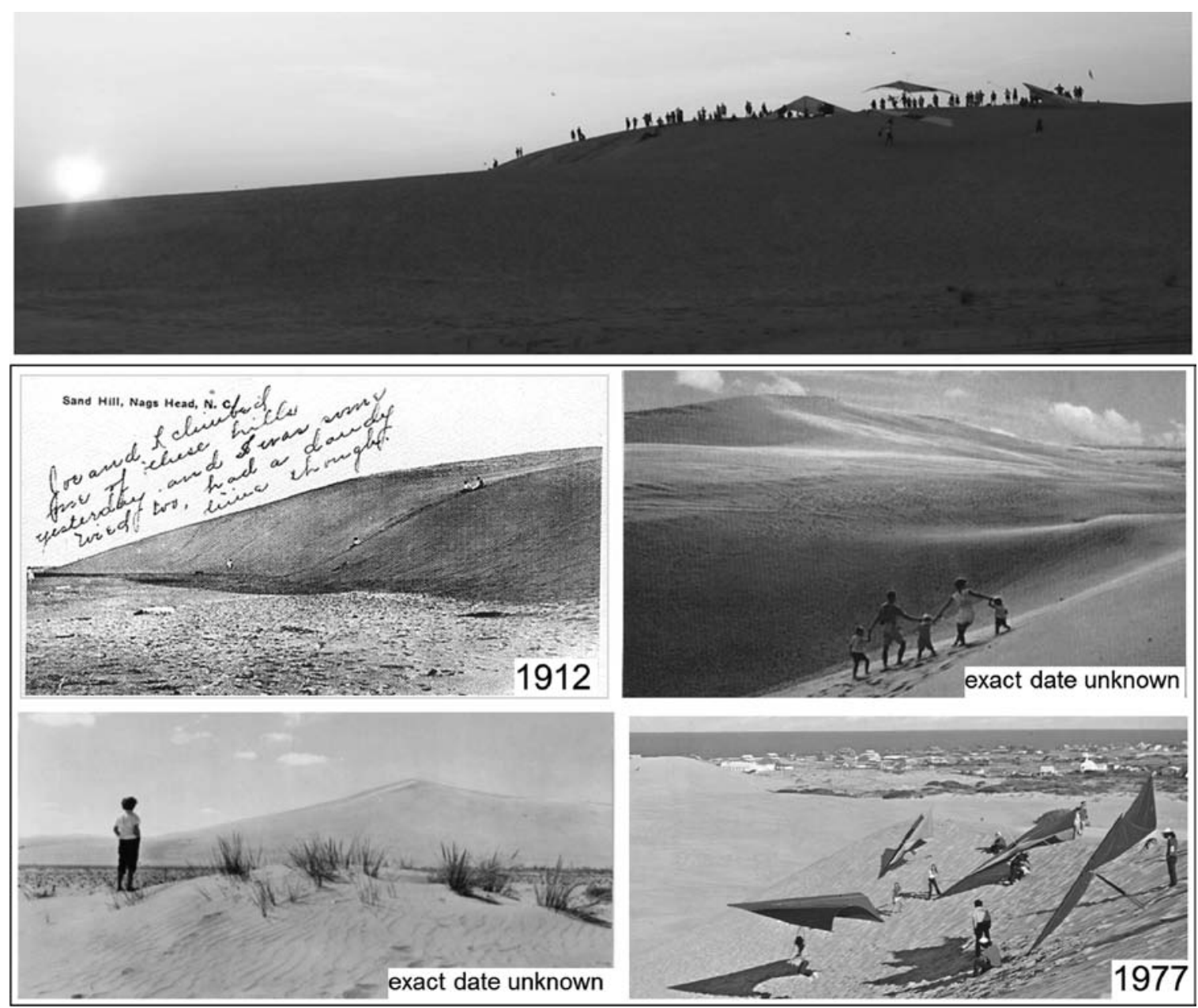

Figure 2. Recreational activities are hang gliding and sunset watching (top). Historical postcards indicate that the dunes were used for recreation long before the state park was established (bottom four). They also document changes in the dune shape and sparse of vegetation.

\section{Data Collection}

Data collection was divided according to the two themes found in the previous research literature: natural processes and human activities. To learn about natural processes, remote sensing data including aerial light detection and ranging (LiDAR) elevation surveys as well as historical maps and aerial photos were analyzed. Vegetation and development data were obtained by classification of aerial imagery. Visitor expectation and preference surveys as well as informal conversations with stakeholders (Mitas, 2006) were conducted to learn about human processes. Photos and informal observations were collected to study interactions between natural and human processes. Conversations with visitors and park management during a series of biennial site visits over the past 10 years provided additional information about the management issues and visitors concerns.

Geophysical Data. Digitized contours and point elevations acquired by stereophotogrammetry, realtime kinematic GPS, and airborne LiDAR during the time period 1974-2008 were transformed into a series of seven (1974, 1995, 1998, 1999, 2001, 2007, 2008) digital elevation models that fully capture 

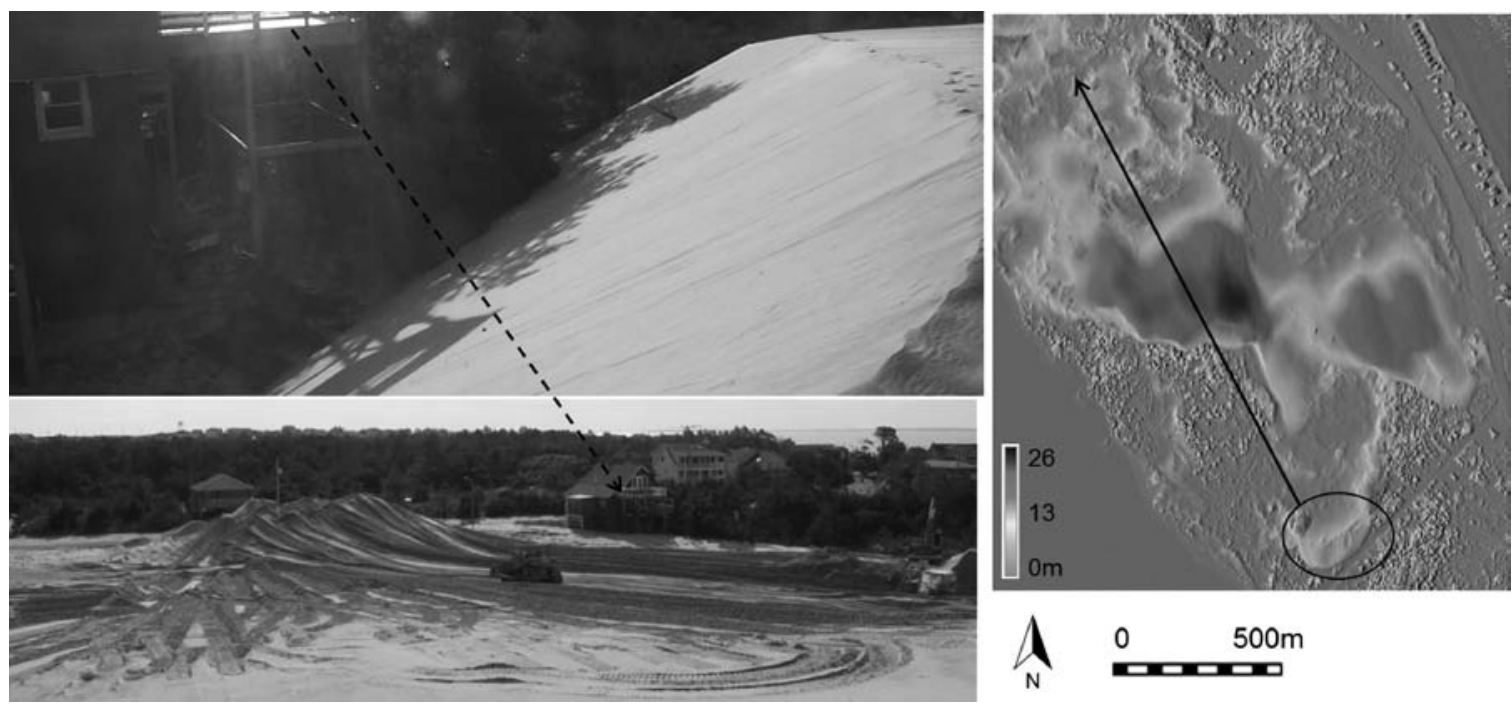

Figure 3. Removal of a small south dune in the year 2003. Dashed line indicates the location of a threatened house in both photos. Solid line on the map shows location of the south dune and a disposal site for removed sand.

the 3D dune field evolution (Mitasova, Overton, \& Harmon, 2005; Weaver, 2011). Older elevation data (pre-1974) were rather limited and included profiles (1928, 1931, 1935; Feltner, 1948) and spot peak elevations $(1917,1953)$, providing information only about the main dune height without describing its shape. Historical evidence was combined with analysis of recent data to assess the geomorphological evolution of the dune field.

Historical Maps and Aerial Photographs. Scanned historical maps 1795-1953 were acquired through an on-line repository of nautical charts and topographic maps (National Oceanic and Atmospheric Administration, 2012) and provided a historical perspective of the development of the study area into a tourist destination. Aerial imagery was available from 1932, continuing with at least one image per decade until 2009 (Weaver, 2011) (Fig. 4). The selected images were classified and land cover data were derived for assessment of vegetation change and growth of development (Weaver, 2011).

Visitation Levels. Jockey's Ridge State Park collects visitor data using a pneumatic vehicle counter at each parking lot entrance. One vehicle has been assumed to bring, on average, 2.5 people, given that most visitors come with their families. The pneumatic counter also distinguishes buses, which have been recorded as 20 individuals. These multipliers were occasionally verified using observation studies. The monthly and annual visitation levels for years 2002-2011 were available from the park management.

Visitor Preferences. Visitor expectation and preference data collected in a 2005 survey (Mitas, 2006) were reexamined. These data were collected for a master thesis that aimed to explain the Jockey's Ridge experience in terms of what visitors found important. In July, August, and October of 2005, 200 visitors were intercepted at the entrance of the park and invited to take a questionnaire with them during their visit, and hand back the questionnaire when they exited the park. The questionnaire contained open-ended questions about preferred features and processes of the dune. The first question, "What do you feel is unique or special about Jockey's Ridge," was aimed at eliciting visitors' general reactions to the dune's features. With the subsequent questions, "How do you think time has changed Jockey's Ridge," and "How do you feel about these changes," we focused visitors' attention to processes in particular, and aimed to find how much they preferred certain processes and not others. We analyzed responses 

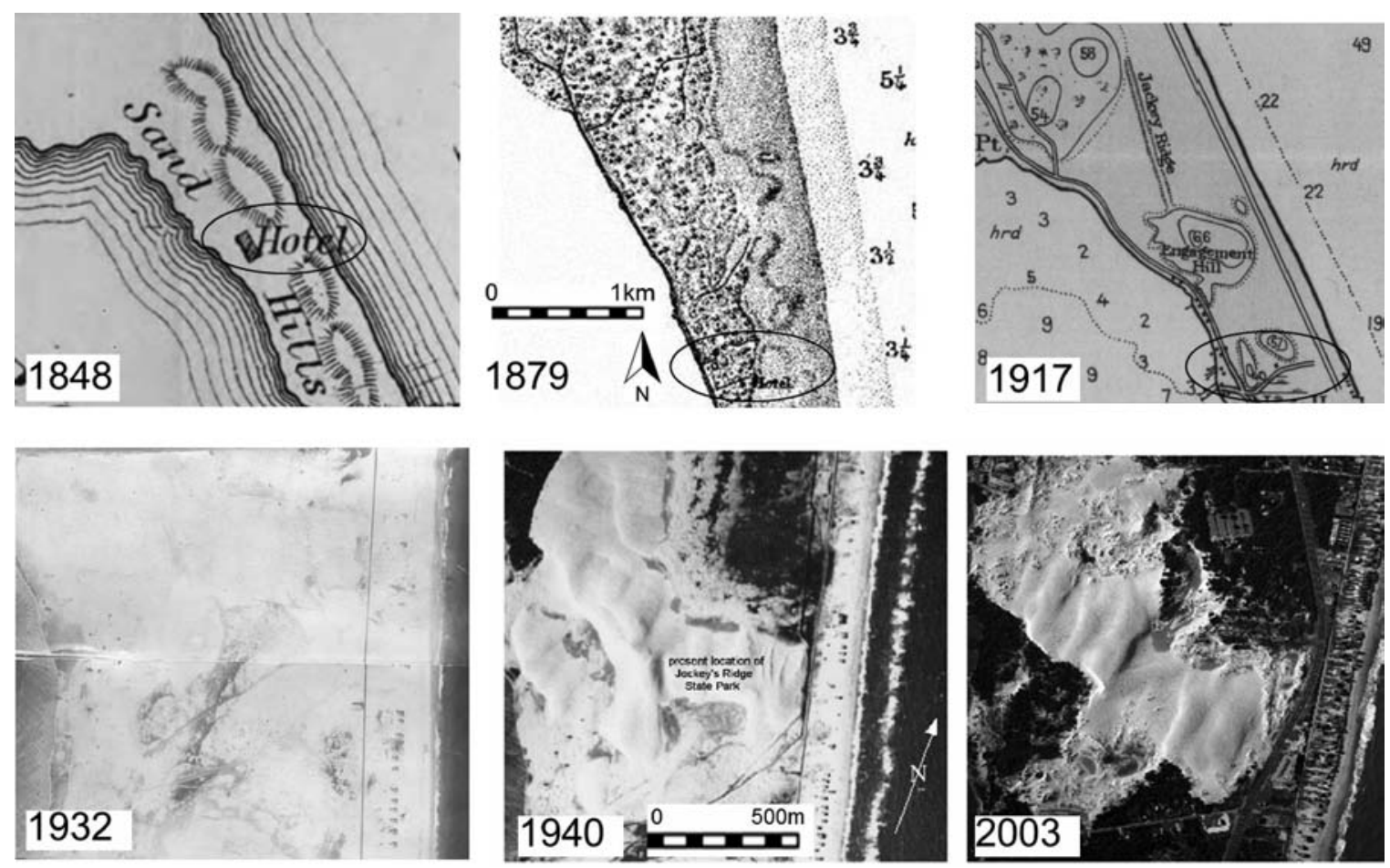

Figure 4. Historical maps and airborne imagery document the presence of dunes and change in vegetation cover.

to the open-ended items using interpretive thematic coding (Braun \& Clarke, 2005).

Stakeholder Perspectives. The data collection also included informal conversations with stakeholders, including park management, a representative of the park's nonprofit foundation, and the CEO of the concessionaire that offers hang gliding lessons in the park. In a subsequent visit, the findings from the visitor survey were presented to park management and the foundation, leading to further conversations about the park's condition and future. Later visits included meetings with park management in 2007 and 2011. Rather than formal recording and analysis, which may have aroused suspicion in the close-knit Outer Banks community, these conversations were described in field notes and discussed among the research team to identify parallels and contradictions to the themes identified in the visitor survey.

Visitor Photographs and Postcards. Photographs with content concerning the evolution of the dune were collected. These included historical postcards (Fig. 2), photos from 1970 to 2000 displayed in the Visitor Center, and our own photos. Starting in 2003, members of our research team began visiting Jockey's Ridge biennially and photographing the dunes. Rather than taking identical "overall” views of the dune on each visit, the focus was on systematic documentation of change-markers to suggest the movement of sand and changes in height, advancing or dying vegetation, and evidence of visitors and their impacts. These photos were treated as a source of comparative evidence, looking for confirmation and disconfirmation of our findings from geophysical, visitor, and stakeholder data. In general, evidence from the photos was consistent with visitor and stakeholder accounts. The most recent photos, in particular, were able to fill some gaps in understanding left by the geophysical data and airborne imagery. For example, photographs revealed spread of vegetation over the dune's southern slip face and documented some earlier attempts of the park management to control the migration of dune using disposed Christmas trees. 


\section{Results}

The data told a story of complex interaction between sand, wind, vegetation, development, management, and visitors at Jockey's Ridge. While each type of data was analyzed on its own, it was also useful to look for confirmation as well as contradiction in the three stories that emerged: geophysical processes, the task of managing a living dune, and the potential impacts of visitors on the landscape.

\section{Geophysical Processes}

Geomorphological analysis showed that the dunes have steadily migrated south at rates of $3.0-5.3 \mathrm{~m} /$ year since 1975 (Weaver, 2011). The data indicate that the peak elevation grew from $20 \mathrm{~m}$ in 1917 to $42 \mathrm{~m}$ in 1953. At some point between the years 1953 and 1974, the main dune started to lose elevation. The elevation decrease may have been triggered by the impact of an extreme storm event (Ash Wednesday "Nor'easter," or coastal winter storm, in 1962), followed by vegetation growth that diminished sand supply (see Fig. 4). The highest dune peak lost elevation at a rate of approximately $0.4 \mathrm{~m} /$ year between the years 1953 and 2004 (from $42 \mathrm{~m}$ to the current 21-22 m) (Fig. 5), with no loss in elevation observed after the year 2004 (Weaver, 2011).

The classification of aerial imagery quantified the gradual increase in the spatial extent of vegetation, and outside the park development since the 1930s (Weaver, 2011). Areas of vegetation have closely followed the migration of the dune, with the dune destroying the spreading vegetation on the leeward side, while new vegetation expanded on the windward side and further limited sand supply (see Fig. 4). In the year 2010, for the first time, vegetation was observed climbing over the slip face of the dune.

After the park was established, housing development continued at a fast pace outside the park. Over the past decade, roads and houses replaced sand and vegetation. By 2009, only 25\% of the area neighboring the park remained sandy, while 22\% was developed and 52\% was covered by vegetation. Within the park, $62 \%$ of the area still remained sandy, decreasing from 93\% of sandy area in 1932. This change is due to growth in vegetation.

\section{Managing a Living Dune}

In general, the data concerning management efforts tell a story of success under difficult circumstances. The movement of the dune, starkly identified by Jockey's Ridge marketing materials, stakeholders, and visitors as an essential process to the park, has caused the park management a number of challenges over the past 20 years. The encroachment of the dune on a road and a house on the southern end of the park (Fig. 3) and on the highway on the eastern side were especially difficult to manage. Barriers constructed from sand fences and disposed Christmas trees have been installed on the dunes with limited success to prevent encroachment (Fig. 6). On the south side of the park, as explained above, encroachment eventually required moving a large volume of sand to the northern, windward side

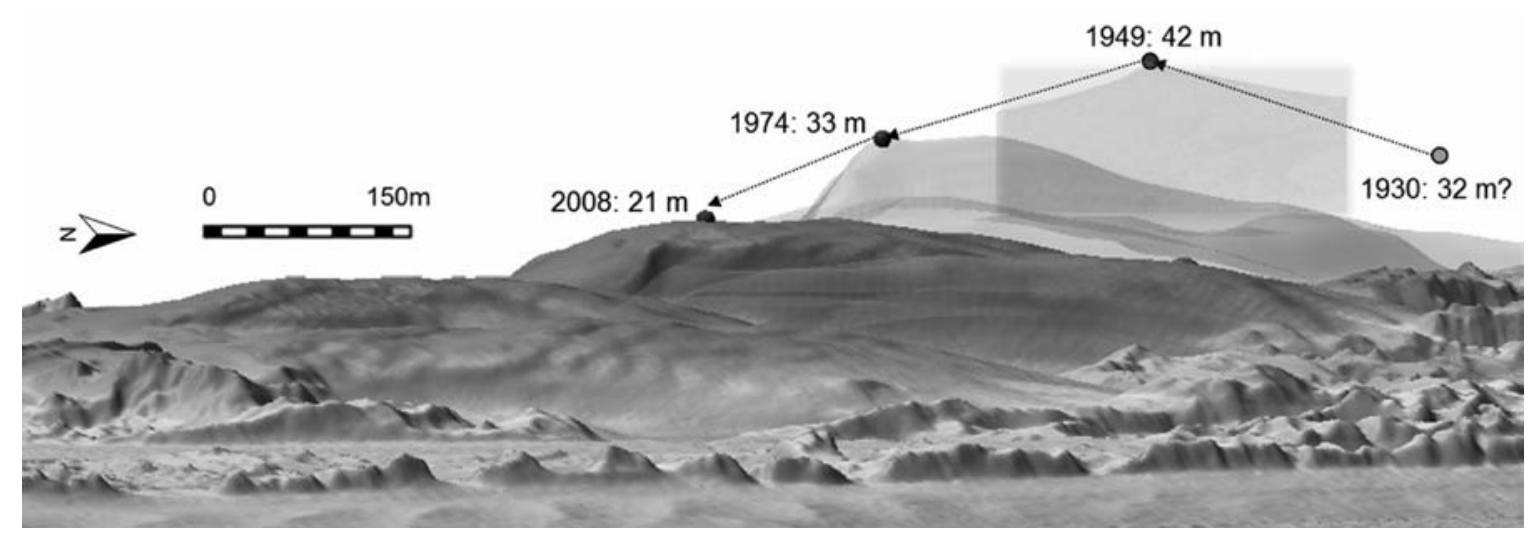

Figure 5. Evolution of height and shape of Jockey’s Ridge dune based on geomorphological data and literature. 

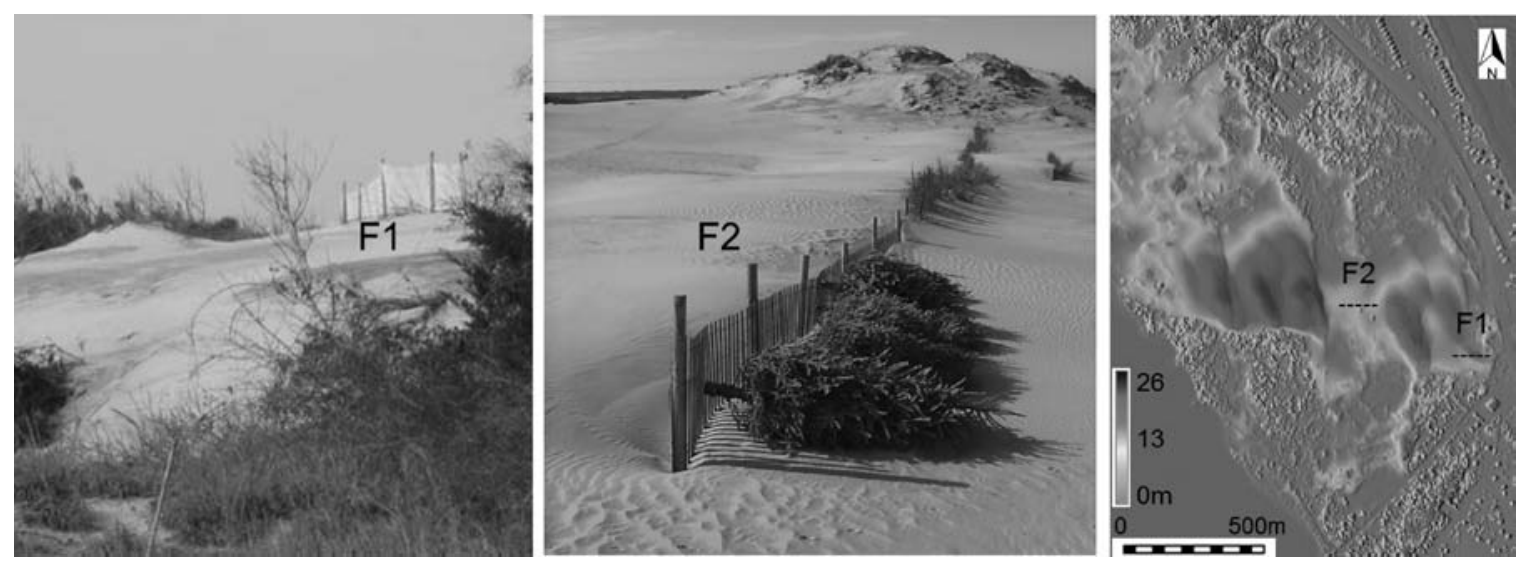

Figure 6. Sand fences and discarded Christmas trees used to slow the dune migration. The map shows their location on a digital elevation model.

of the dune field. While visitors were not aware of this situation, stakeholders spoke about it in tones of fear and dismay, while photos confirmed the relative "trauma" of this process, distinctly showing an "injured" dune and construction equipment that seemed out of place in the landscape (see Fig. 3).

Besides encroachment, the decline of the dune's height has also caused concern. This decline produced slight but clearly negative feelings in many of the stakeholders and in some visitors. Stakeholders responsible for the hang gliding concessionaire in the park were the most affected, and were the strongest advocates of intervening-perhaps by removing vegetation on the windward side to release sand, or by placing sand fences on the top of the highest dune itself- to stop or reverse the decline in height. Two counterarguments prevented the park from taking such measures. First of all, under pressure from budget cuts, the park could not afford labor or materials for all but essential landscape interventions, as the day-to-day efforts of informing and protecting visitors and maintaining facilities consumed nearly all resources. Second, the status of the dune as a feature of a State Park was intended to protect this landscape from substantial, noticeable alterations. Putting a sand fence on top of the dune, for example, would violate this guideline.

Visitors' responses to the 2005 questionnaire provided compelling support for this limited intervention policy. Two valuable aspects of the visitor experience were found in the data: the size of the dune, expressed in terms of height, volume, or amount of sand; and the movement of the sand and corresponding changes in the shape of the dune. It would seem, then, that the decline of the dune's height would contribute negatively to the visitor experience in terms of the size of the dune, but would also enhance the visitor experience in terms of showing movement of sand and changes in the shape of the dune. A number of visitors, furthermore, explicitly stated that changes in the shape of the dune were either acceptable (“OK," "Fine by me”) or actually valuable ("Great," "Interesting”) if these changes were caused by "natural” processes such as wind erosion and advancing vegetation. Correspondingly, a number of visitors expressed negative feelings about the decline of the dune if it was due to surrounding (human) housing developments.

Based on these findings, the thesis of Mitas (2006) confirmed to park management that costly interventions such as the 2003 sand removal should be avoided when possible, visible interventions such as sand fences should be limited to the perimeter of the park, and visitors should be better informed about the processes causing the dune to decline. Thus, the park has maintained this light-handed management policy, and improved visitor information with new museum exhibits in the Visitor Center. Subsequent visits suggested that the park is relatively successful in protecting the landscape and providing a valuable experience for visitors. The dune has remained sufficiently large for the hang gliding concessionaire 
to operate. The dune can still be clearly seen from surrounding roads and continues to inspire pride in stakeholders.

\section{Visitor Impacts}

The policy at Jockey's Ridge of allowing visitors to walk freely over the entire dune has led to a distinct visitor experience. Unlike at some parks where visitors are more conventionally confined to trails, visitors' interaction with the Jockey's Ridge dune landscape is playful and visceral. Each of our visits to the park during warm weather showed children and adults not only walking over the dune, but also running around, playing in or with the sand, and rolling or running playfully down the side of the dune. Such close and spontaneous contact with natural elements, according to our observations as well as the 2005 questionnaire, leaves visitors with positive feelings about the site and about their time there. Furthermore, several visitors wrote of the opportunity to "learn about nature," although this outcome may be linked more to exhibits and lectures in the Visitor Center.

Allowing visitors free access to the entire dune has certain disadvantages. On very hot days in July and August, months when visitation is highest, visitors experience health risks such as burns from hot sand, which can be $10-20^{\circ} \mathrm{C}$ warmer than surrounding temperature, and dehydration. According to park management, extensive warnings (on signs, on the website, and personally) as well as occasional medical assistance (by small all-terrain vehicles that can be quickly driven over the dune) are required during these times.

Also, visitors, stakeholders, and research colleagues have raised the issue of impacts on the height and shape of the dune caused by the large numbers of visitors walking over its surface. After days of heavy visitation, the dune, otherwise smoothed and rippled by the wind, is completely covered in footprints (Fig. 7). It seems plausible that such disruption to the surface of the dune would affect the height of the dune over the long term. Stakeholders and researchers have even suggested in informal conversations that the decline of the dune's height from 1950 to 2005 could be largely due to the impact of visitors walking all over it.

Data do not support this supposition. The dune already lost significant elevation between the years 1953 and 1974, before the park was established and when the number of visitors on the dune and at the Outer Banks was relatively small. Geomorphological data show that the 1953-2001 trend of decline in the overall height of the dune has stopped and, despite a major hurricane and several notable storms, Jockey's Ridge has remained around $22 \mathrm{~m}$ in height between 2002 and 2008, although the location and shape of the highest peak continues to change (Weaver, 2011). On the other hand, after a temporary decline below 1 million annual visitors in the years 2004 and 2005, visitor numbers have risen to their highest levels on

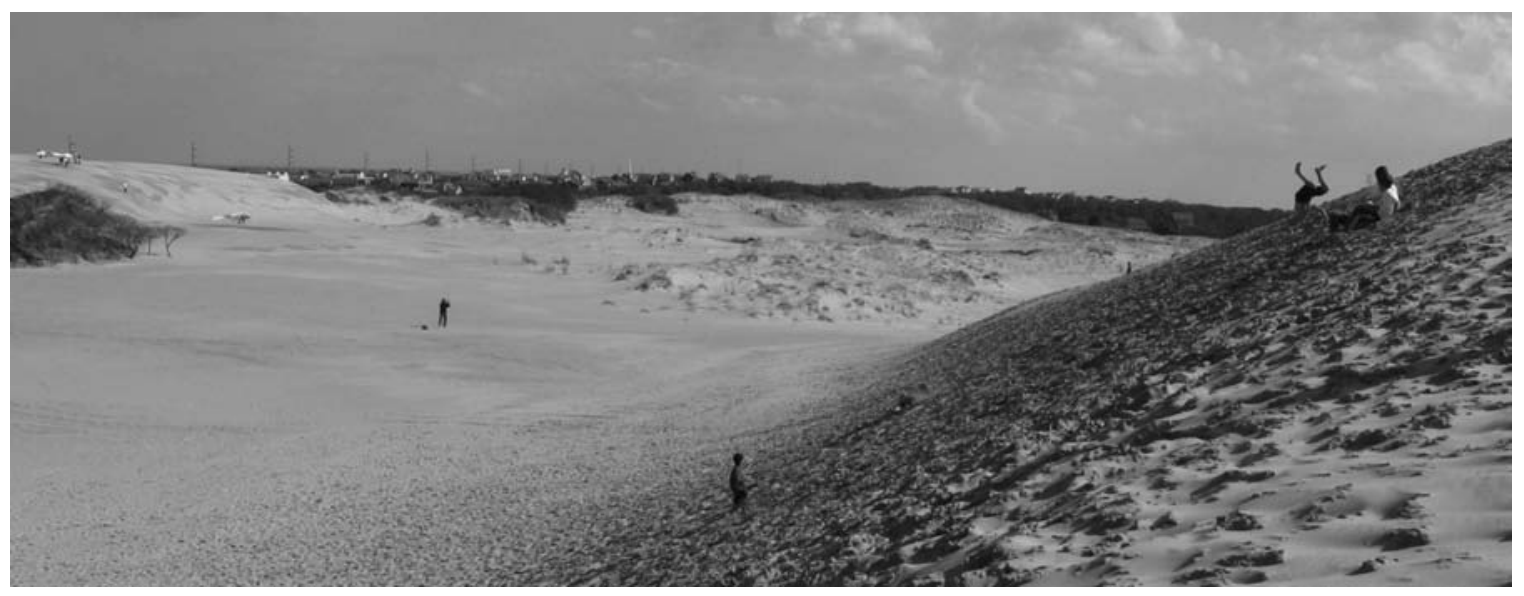

Figure 7. Footprints on dune at the end of a busy day at Jockey's Ridge. Rainfall left the sand moist and prevented smoothing of the dune surface by aeolian sand transport. 
record in the past 5 years, reaching a peak of over 1.5 million in 2007. If visitors impacted the height of the dune, we would expect these trends to be reflected in the changes in the dune's height. They are not. Instead, the research indicates that interactive processes of wind erosion and vegetation explain the changes in the height and shape of the dune (Havholm et al., 2004; Mitasova et al., 2005; Weaver, 2011).

\section{Discussion}

Jockey's Ridge has been successfully managed as a living landform-an interaction between geophysical and biological (including human) processes. Visitor and observational data suggest that dunes managed as living landforms, such as Jockey's Ridge, can support active recreation and education in a way that heavily altered or stabilized landscapes cannot. In particular, the wind- and vegetation-fueled changes in the dune were experienced as interesting and valuable by visitors. Visitors also appreciated the opportunity to walk freely over the entire dune. Moreover, the minimal and intermittent interventions, with the exception of the 2003 sand removal, have been relatively costeffective. Many dune management practices, such as removal of vegetation to "reanimate" static dunes, come at high costs and risk that the process may get out of control under unexpected weather conditions. Landscape modifications designed to limit visitor movement, though advocated in the dune management literature (Batanouny, 1999; Meulen \& Salman, 1996; Yang et al., 2012), are also costly.

In fact, the data contrast with the recommendation by Batanouny (1999), Davies et al. (1995), and Yang et al. (2012) to limit visitors' movements in parks. The data show that visitors to Jockey's Ridge benefit from the opportunity to play, learn, explore, and be physically active over the entire dune, without being confined to certain "trails." On the other hand, our data do support balancing benefits of human activities against their potential impacts, as Meulen and Salman (1996) argue. Jockey's Ridge is open over its entire area, but only visitors traveling on foot are allowed, while vehicular traffic is not. Small, stabilized vegetated dunes are sensitive even to free movement on foot and may become severely degraded from the 1,000,000+ visitor levels seen at Jockey's Ridge. On the other hand, our data suggest that large, active dunes such as Jockey's Ridge can handle free pedestrian visitor movement and thus offer a unique visitor experience when compared with smaller vegetated dunes where the visitors are, perhaps rightfully, restricted to trails. These smaller, vegetated dunes have likely inspired the restrictive approach of dune management research previously. A more permissive approach to nonvehicular recreation seems to fit better with larger dunes.

\section{Conclusion}

A limited intervention policy has allowed Jockey's Ridge to retain its dynamic geophysical character and diverse flora and fauna while offering visitors a valuable experience. Though management challenges were unavoidable, the data suggest that costly interventions on the landscape or visitor movements were rarely warranted. A management approach that integrates geophysical and biotic processes (Meulen \& Salman, 1996), treating flora, fauna, and human recreation as inherently valuable, has been successful.

The detailed analysis of the Jockey's Ridge situation was only possible thanks to an integrated mixed-methods approach. While such approaches are becoming more acceptable in tourism research, complex site management problems demand such approaches to reconcile competing interests and see a "big picture" of biological and geophysical interactions. Furthermore, vision is needed from government agencies to fund collections of geophysical data, such as the LiDAR measurements that made possible the digital elevation models featured here. Finally, when budgets allow, more extensive and systematic collection of visitor and stakeholder data can provide further insight. The investment pays off in knowledge that can foster resources such as coastal dunes for generations to come.

\section{Reflections on Technology and Infrastructure}

Beyond the context of Jockey's Ridge, our findings highlight the need for coastal destinations to invest in monitoring technologies. This includes new geospatial technology for mapping and data analysis (LiDAR, aerial images, GIS tools, geovisualization), which provide data and tools to improve understanding of processes driving changes in 
landscape. Monitoring human behavior can also be aided by new technologies, however. Mobile applications and social media, in particular, could offer a wealth of data on individuals' recreational experiences in coastal contexts. Our findings highlight the importance of managing the interaction between recreational activities and natural processes, rather than dealing with people or nature in isolation. The foundations of good decisions in this regard are rich and complex data. The excitement about new technologies for collecting such data was tangible at the 7th Coastal and Marine Tourism Congress (CMT '12), held in Breda, The Netherlands in 2012.

Our findings also reflect the vigorous dialogues at CMT ' 12 about the challenge of managing coastal tourism infrastructure in the context of (increasingly) powerful natural forces. From our study and others presented at CMT '12, it is clear that such infrastructure needs to be managed with nature rather than against nature. Such a balanced approach is not only more ethical, but leads to higher quality tourist experiences.

\section{Acknowledgments}

We appreciate the useful feedback from the anonymous reviewers and delegates of CMT '12 who visited the presentation of this paper. We also thank the management of Jockey's Ridge State Park for their encouragement and support.

\section{Biographical Notes}

Ondrej Mitas has worked as lecturer and researcher and has specialized in emotion measurement and mixed methods at NHTV Breda University of Applied Sciences in the Netherlands since earning his Ph.D. at Penn State in 2010. His research focuses on happiness, well-being, quality of life, and, especially, positive and meaningful emotions in the tourist experience. He currently manages research at NHTV's Academy for Tourism.

Helena Mitasova is Associate Professor at the Department of Marine, Earth and Atmospheric Sciences at the North Carolina State University in Raleigh, NC, USA. Her research interests include geospatial modeling for sustainable land use management, terrain analysis, and geovisualization. She is a charter member of Open Source Geospatial Software foundation.

Gene Brothers is an Associate Professor at the Department of Parks, Recreation, and Tourism Management at the North
Carolina State University in Raleigh, NC, USA. His research interests include equitable and sustainable tourism development as well as the analytics of touristic choice behavior. In addition, his research emphasis is focused on the balance between destination supply and demand.

Katherine Weaver received a master's degree from the Department of Marine, Earth and Atmospheric Sciences at North Carolina State University in Raleigh, NC, USA. She works for the Eastern Division Conservation Science Office of The Nature Conservancy in Boston, MA, USA as a regional GIS Analyst. Her research interests include coastal conservation and regional marine geospatial analysis.

\section{References}

Batanouny, K. H. (1999). The Mediterranean coastal dunes in Egypt: An endangered landscape. Estuarine, Coastal and Shelf Science, 49, 3-9.

Berger, G. W., Murray, A. S., \& Havholm, K. G. (2003). Photonic dating of Holocene back-barrier coastal dunes, northern North Carolina, USA. Quaternary Science Reviews, 22(10-13), 1043-1050.

Braun, V., \& Clarke, V. (2006). Using thematic analysis in psychology. Qualitative Research in Psychology, 3(2), 77-101.

Davies, P., Williams, A. T., \& Curr, R. H. F. (1995). Decision making in dune management: Theory and practice. Journal of Coastal Conservation, 1, 87-96.

Feltner, C. E. (1948). Beach erosion in North Carolina. The Department of Engineering Research Bulletin No. 37: North Carolina State College Record, 47(4).

Froidefond, J. M., \& Legigan, P. (1985). La grande dune du Pilat et la progression des dunes sur le littoral Aquitain. Bulletin Institut Geologique du Bassin d'Aquitaine, 38, 69-79.

Havholm, K. G., Ames, D. V., Whittecar, G. R., Wenell, B. A., Riggs, S. R., Jol, H. M., et al. (2004). Stratigraphy of back-barrier coastal dunes, Northern North Carolina and Southern Virginia. Journal of Coastal Research, 20(4), 980-999.

Judge, E., Courtney, M., \& Overton, M. F. (2000). Topographic analysis of dune volume and position, Jockey's Ridge State Park, North Carolina. Shore and Beach, 68(4), 19-24.

Kinglsey, J., \& Bachman, K. (2009). Insiders'guide to North Carolina's Outer Banks. Guilford, CT: Globe Pequot Press.

Kuitel, P. (2001). Conservation and management of the Mediterranean coastal sand dunes in Israel. Journal of Coastal Conversation, 7, 183-192.

Martinez, M. L., \& Psuty, N. P. (Eds.). (2004). Coastal dunes: Ecology and conservation (Ecological Studies, 171). Berlin: Springer-Verlag.

Meulen, F., \& Salman, H. P. M. (1996). Management of Mediterranean coastal dunes. Ocean \& Coastal Management, 30(2), 177-195. 
Mitas, O. (2006). The visitor experience at Jockey's Ridge. Master's thesis, North Carolina State University.

Mitasova, H., Overton, M., \& Harmon, R. S. (2005). Geospatial analysis of a coastal sand dune field evolution: Jockey's Ridge, North Carolina. Geomorphology, 72, 204-221.

National Oceanic and Atmospheric Administration. (2012). Digital coast. Retrieved May 7, 2013, from http://www. csc.noaa.gov/digitalcoast/

Pelletier, J. D., Mitasova, H., Harmon, R. S., \& Overton, M. (2009). The effects of interdune vegetation changes on eolian dune field evolution: A numerical-modeling case study at Jockey's Ridge, North Carolina, USA. Earth Surface Processes and Landforms, 34(9), 1245-1254.
Runyan, K. B., \& Dolan, R. (2001). Origin of Jockey’s Ridge, North Carolina: The end of the highest sand dune on the Atlantic Coast? Shore and Beach, 69, 29-32.

Tastet, J. P., \& Pontee, N. I. (1998). Morpho-chronology of coastal dunes in Medoc: A new interpretation of Holocene dunes in Southwestern France. Geomorphology, 25(1), 93-109.

Weaver, K. (2011). Impacts of vegetation and development on the morphology of coastal sand dunes using modern geospatial techniques: Jockey's Ridge case study. Master's thesis, North Carolina State University.

Yang, B., Madden, M., Kim, J., \& Jordan, T. R. (2012). Geospatial analysis of Barrier Island beach availability to tourists. Tourism Management, 33(4), 840-854. 